\title{
Collaboration on the web - Chances of participation in a formal education context
}

\author{
Jane Fleischer*, Klaus Bredl \& Ramona Weise
}

University Of Augsburg

\section{Abstract}

This contribution addresses the options and chances for an alliance between students' participation and the adoption of digital media in a context of academic education at universities. Under certain circumstances these two aspects are able to develop an additional benefit for the process of teaching and learning. Collaboration serves as an exemplification to show imaginable and straightforward ways for such alliances. All of the processes presented in the contribution already have been realized. The following introduces the case study and summarizes every potential and challenge of collaboration. According to the summary every kind of collaboration will be allocated in the correlation of participation in the web and at the academia.

Keywords: Teaching, Multi-User Virtual Environments, Learning.

Received on 01 November 2011; accepted on 01 June 2012; published on 10 August 2012

Copyright $\odot 2011$ Fleischer et al., licensed to ICST. This is an open access article distributed under the terms of the Creative Commons Attribution licence (http://creativecommons.org/licenses/by/3.0/), which permits unlimited use, distribution and reproduction in any medium so long as the original work is properly cited.

doi: 10.4108/eeel.2012.07-09.e4

\section{Introduction}

The term participation is on its way to gaining more importance. It is more and more understood by practitioners as well as scientiststhat the term not only refers to political participation. Two areas of participation are essential in this paper: On the one hand the participation in educational processes may help to acquire competences in the field of political education. This part is represented by an example of participating in higher educational apprenticeship. On the other hand the paper deals with the participation in and with the multifunctional possibilities the internet offers. These possibilities increased with the rise of the so called social web.

The purpose of this contribution is to show possible junctures of both fields on the basis of a case study and to

*Corresponding author. Email: jane.fleischer@phil.uni-augsburg.de consequently offer suggestions for an (increased) input of digital media for academia education.

First it has to be clarified in this context, what exactly is meant by the term participation. Despite the variety of existing definitions, researchers, who give attention to the field of participation, which does not only take place in the narrow sense of the political context, are rare.

Sturzenhecker studied the subject matter in the field of scholar education and describes participation in a broader sense as

the right to take part in collective and public discussions and decisions of institution, politics, state and society as a free and equal subject, and to notice own interest to participate in public, to find solutions with a team, to define them, to check them, to be responsible for them and to revise them at the same time. Participations is the praxis of democracy (2005, p. 30; translation by the author).

This practical experience of democracy is to be found in all areas of society. A classification of participation 
forms intolevels of society, where they take place, appears reasonable to systematize existing definitions. Collaboration that aims at changing or contributing to the system can be grasped on the macro level. In organizational areas participation takes place on the meso level. In this case the aim is to have an internal influence on organizations and society institutions. Individual collaboration processes at the micro level do eventually focus on the influence on living conditions of society members. The main theme of this contribution will deal with both of the last two classifications.

\subsection{Participation in education processes}

The Participation in political education and collaboration processes, which happen increasingly in a virtual social presence (Bente, Krämer,\& Petersen, 2002; Jolie, S., Katzky, U., Bredl, K., Kappe, F. \& Krause, D., 2011) based on informal interaction, requires the acquisition of an altered 'social' media expertise in an upstream formal education context. With the acquisition and testing of political capacity to act, which cumulatively take place in the context of the web, it also became necessary to consider this capacity to act as aim of didactic concepts. Collaborative learning and working surely is a central aim of competence in the matter of participation to build up a foundation for a growing virtual socialization (Bredl, K. \& Herz, D., 2010). .

Von Saldem (2008) differentiates, aside from the already mentioned political and organizationpsychological approach, furthermore, a pedagogic approach, which is even more manifest to the here treated subject matter. Sturzenhecker implements for this that "in pedagogic themes there has to be emphasized that participation is not to be accorded as the mercy of a wellmeaning pedagogue, but to be claimable and realizable as a right for all children." (2005,p, 30; translation by the author)

Two aspects of class design show junctures between representative decision and participation of learners: on the one hand research for the course's orientation on lifestyle and situation, on the other hand the demand for a scientificorientation (Saldern, 2008,p. 571).

With 'learner-orientated lessons' as reference there can be found efforts and also researches which focus on more participation of the consignee in all areas of education. Already in 2000 the Standing Conference of the Ministers of Education and Cultural Affairs of the Länder in the Federal Republic (KMK) elaboratedthe significance of participation. Thus, the capacity to act supports as "self-, social-, subject- and methodical competence". (KMK 2000; cited by Sturzenhecker, 2005,p. 31; translation by the author) Similarly, the demand for increased contribution of students has arisen along with the Bologna process (compare Eckardt, 2005).

This is closely connected to an intensified orientation on the competence building of education consignee.
Participation plays a decisive role in the process of lifelong learning, which is in need of support (compare The European Ministers for Education 1999) and especially in the section on scientific advanced training (compare Schäfer, Bredl, Holzer, Jütting, \& Schilling, 2006). Having possibilities for participation already established in academia means to lay the foundation for a long-lasting process of development. In the context of education participation acts a part on different levels. Concerning this topic Von Saldernnames,in additionto the teaching methods and their organization, the relationship between learner and teacher as well as the overall organization of an education institution (Saldern, 2008,pp. 571-572).

On the higher education level this list can be complemented by the level of competence aims. It is still to be considered that even under those circumstances all learners should have a right for realizable possibilities of participation. Considerable and necessary for the enabling of (political) collaboration on a social (macro) level seems to be adequate preparation on the meso level of the institutionalized competence-oriented academic institution. On the micro level participation deduced from this for the design of courses can be way and goal.

Possibilities of participation within the dimensions of an academic education offer a low-threshold approach to the own right of co-determination. Theoretically it is possible to include all students on the same level of education and to consequently grant them a right of codetermination in terms of the course planning, the operations layout, the didactic and content design and even the grading. By means of this, learners are activated and no longer only consumers of a - from the outside dictated - instrumentality. In contrast, the learner attains the assurance that his didactic concept and his considered aims for competence meet with interest. At the same time students are in a position to not only acquire knowledge but also develop sustainable competences.

That participation as a matter of education is not only a politically motivated demand but by all means it does have an influence on the development of participants, which has been shown in several studies (compare Dür, Bauer, Grossmann, \& Mravlag,2002; Dietscher, 2005). Dietscher,who offers a synopsis of studies about constitutional impacts of participation in educational contexts in particular, arrives at the conclusion that there are two preconditions for the assignment of participation as a matter of education: on the one hand a fitting didactic design and on the other hand the learners' willingness to abandon parts of their habitual role. Therefore, the development of a new position looms large in the process of learning and teaching (Dietscher, 2005). Are the appropriate preconditions given may the participation also support demonstrably next to the here researched learners' well-being also their psychosocial competences and the as well closely linked learning success (ibid.: 9). Naturally, the learners' participation is provided with - as for example in collegiate project groups - a decisive significance for their learning success: 
When it's being studied, then this is explained in terms of the approach of the situated learning to be a big part of participation in a social group. In this process there will be not only acquired applied knowledge, but there will be also passed on difficult to explicate experiences and their meaning discussed. As the learner as part of a society takes over activities, which increase in intensity step by step, he builds up expertise bit by bit. (Reinmann (in press), p. 3; translation by the author)

In contrast to those outcomes it is surprising that participation as a matter of academic education is still far behind all of the current possibilities of realization. Therefore, there exists in most cases only the participation of students in forms of group work as collaborative acquirement of contents - contents which are mostly named by the teachers and leave hardly tolerance for own ideas and opportunities for self-determination. And even this minimal realization can only be found in altering measures in the different departments.

\subsection{Participation in and with the web}

In the second relevant part of this contribution concerning the participation in the web - there will be pointed out the change of web usage towards the upcoming of the social web. Hence, the World Wide Web, which had been used primarily in a passive mode to simply access information online in former times, now has turned into a kind of "participationweb" (Fisch \& Gscheidle, 2008) with the introduction of bloggingservices, wikis and social networks - just to name the most important ones. The users are turning from consumers into "prosumers" (Toffler, 1980) or rather "produsers" as a consequence of this development (compare Bruns, 2010). New media offers create a multiple of possibilities - in particular possibilities of participation. As Wagner states for the example of wikis: "Wikis demonstrate the possibility of aggregating small information chunks from many contributors into meaningful knowledge aggregates." (Wagner, 2009, p. 2).Another example is described by Klaisubun, Honma, Kajondecha and Takashi (2009). They describe the process of Collaborative Information Gathering (CIG) with the help of Social Bookmarks. Last but not least Honeycutt and Herring (2009) give a third example for a possible collaboration tool online. In their analysis they found out that "Twitter will soon come to be used in formal collaborative contexts, as well-for example, in work involving distributed teams, much like instant messaging before them" (n.p.). Meanwhile corporate microbloggingtools like Yammer $^{1}$ evolve from corporate

${ }^{1}$ https://www.yammer.com

${ }^{2}$ http://wikileaks.org/ instruments for collaboration to complex social network platforms.

However, it remains to be emphasized, which commonly tends to be forgotten in this context, that even in the 'old' internet there had been different ways of participation (for example bulletin boards) and that those have been used, too (Fisch \& Gscheidle, 2008).

Participation in terms of collaboration and cooperation is meant hereby in the context of the internet as mass media and therefore also as a chance of taking part in the determination of the public opinion. In contrast to the conventional mass media is the relation of sender and receiver affected by a many-to-many-relationship in this case. Still, it has to be pointed out that participation in terms of influencing the public opinion depicts rather an ideal, since the taking part requires a political engagement.

This illustrates also reality: in this way social media platforms establish new potentials to participate on a macro level. Contributions to the public opinion can be providedby posted articles in personal blogs or, for instance, also by the currently disputed announcements of information or publications of (non personal) data via scientific media as for example Wikileaks ${ }^{2}$. A consolidated view indicates, however, that this new form of participation again arouses discussions at this point, which has been initiated by the possible violation of the data security.

On the meso level of organizations the - for example OpenSource movements permit to participate in the organization and development of media. Still, there can only be spoken on a broad usage in the range of the micro level. Several platforms of the social web - ahead of all the digital social networks, but also bulletin boards and sharing-services - enable chances of participation in terms of an improved individual life quality by self-expression and exchange of experiences on the individual (micro-) level. First and foremost 14to 29-year-olds are, in principle, interested in participation in the web. But there seems to be at least a stagnating maybe even declining interest in possibilities of participation in this group as well (Busemann \& Gscheidle, 2010).

The thought of participation [...] arouse a broad effect, but keeps limited to a group of professionals in online business who contribute which is retrieved by the crowd. Along the lines of decline of interest to participate actively in web 2.0 applications does also decrease the number of those who in fact are willing to do so (ibid.,p. 361; translation by the author).

Merely social networks, platforms which depend on people posting information, are registering a continuous participation growth for the past years (ibid.). Moreover, the participation is in most cases exclusively located in the private sector and is displayed by its phatic communication (Miller,2008; Ketzer et al. 2011). The participation in the web in other sectors of life, as for example an academic context, is rare. In addition, the 
reason for adoption of media in education sectors is only in little cases because of the desire to support collegiate participation. In fact, there predominates in a best case scenario other also not to be disregarded motives as for example the training of media competences; in a worst case scenario media is considered as an end in itself and doesn't offer anything, that reaches beyond the functional contents, at all.

\subsection{Junctures between both fields of participation}

When focusing on participation in the different contexts of their appearance - as has been done in this contribution so far - one important fact gets lost: the human lifestyle as a whole thing. A separation of school/training/job, public and private life only exists in theory. In reality all sectors of life do intertwine, influence and change each other. Because of this the present contribution will pursue the assumption that an increase of participation can only be achieved when this happens in connection with all sectors of life. Therefore it seems reasonable to have media actions, which are already part of the public and private life, integrated into academic education as a method to increase the participation of students in exactly this sector. A possibility for such a juncture is the working form called collaboration. This special form of participation offers great potential for operational areas in virtual spheres of learning (Bredl, K., Groß, A., Hünniger, J. \& Fleischer, J., 2012). Additionally, it requires students to cooperate.

Section 3 describes a project orientated seminar, which was coordinated by the department of media and education technology (IMB) from the University of Augsburg in the summer term of 2010 and which moreover took advantage of this working method. A concept with the title "collaboration online" has been pursued which was supposed to grant students a maximum of participation in the design and realization of the course because of the content structure and the stringent integration of the web as a communication medium (Fleischer, J., Bredl, K., Hünniger, J. \& Weise, R., 2011). At the same time this course was supposed to increase the web participation of all involved students. The outcome of this course has been a blog called 'Tools4You", which will be explicated more closely towards the end of this contribution. With the help of this case study it can be shown how a student's learning progress can be achieved when basic web technology and an additional usage of unknown online services are integrated into an academia course without any guidelines fromthe teacher, but with a goal defined by the students themselves and their collaborative realization. For a better understanding of this procedure the term collaboration will be discussed first. Subsequently, the contents and concepts of this seminar will be briefly outlined and an additional benefit pointed out.

\section{Collaboration vs. cooperation - an overview}

Speaking of team work throughout a learning process there are two terms to be differentiated: collaboration and cooperation. In Contrast to the English these terms are often used as synonyms in German (Neumayer, 2008). But they do not mean the same.

Cooperative working is rather a kind of splitting up work. Collaborative working on the other hand is a shared acquiring of a final result. The result is not based on a pure putting together of single results. The ideas, experiences and knowledge of each single project participant do not collocate but do complete each other. Because the participants learn from each other and are trained in conflict and critic situations the whole group work does gain quality. Single person working is not completely abandoned in this context either, however, the other group participants symbolize the examination authority - they rate and provide advice already in the process of development of the single person working (ibid.). Neumayer outlines the difference between collaboration and coordination fittingly:

Cooperative and collaborative learning are forms of shared learning and do not exclude each other, but do indicate different relations: in a cooperative learning context people work closely together on the same project. This kind of working together is comparable to a puzzle, in which the combination of parts is predetermined by their characteristics. The cooperation orientates itself on a previously fixed final result. This puzzle may not differ from the model. In contrast therefore collaboration is not orientated on the final result, but focuses on processes, specific transformations, which do lead to a learning effect. (ibid.; translation by the author)

When limiting from this point of distinction to the sector of collaboration it has to be differed between collaborative writing and collaborative learning. Collaborative writing means the shared composing of texts, not only the distribution of texts into different topics - the respective editing and eventually the shared putting together - but a shared writing, editing and completing in terms of collaboration.

Such ways of text building can increasingly be found in the social web in particular. The best examples therefore are the already mentioned wikis, but also cooperative blogs (Gersmann \& Mruck, 2006).Collaborative learning happens with participation in terms of reference with others and participation in dialogues. Neumayer describes such learning processes "as an active process of acquirement from a constructive perspective, which leads to the development of knowledge during social interaction" (2008,p. 121; translation by the author). The spirit and purpose of collaborative learning is not the very reconstruction of knowledge, but the appearing of new knowledge - all in all the construction of knowledge. 
Technologies from the social web are very well suited for collaborative learning: learners do for example relate wikis with a rather informal sector, which they know from their social life (Bredl, K., 2008). Thus, subconscious learning occurs which is designed in a very liberal way (Neumayer, 2008).

The question of whether businesses should rely more on social web tools (as for example social networks and blogs) than on traditional on the business restricted knowledge management platforms for collaboration between their employees, is hotly debated (compare Koch $\&$ Richter, 2007). A comparable discussion does not exist for the general support of collaboration in an academic context (Hünniger, J., Fleischer, J. \& Bredl, K., 2011).

Collaboration as a specific type of participation requires the contribution of every single class member: In academia it has to be therefore sought for an equal participation of all those who are involved in the teachinglearning-process.

The integration of web services for academic education seems to be notably appropriate for the development of a culture of participation. In front of such a background the following described course structure had been formed.

\section{3 "Collaboration Online" - A case study}

As already mentioned the seminar "Collaboration Online" took place as part of the bachelor degree course 'Media and Communication' in the summer semester of 2010. The goal was on one hand to impart learners' theoretical knowledge of the topic collaboration. On the other hand students were supposed to work practically with this specific participation supporting working method and also get to know the collaboration itself through it. On the part of the conception, the instructor saw himself as a learning coach who gives regular impulses and advice throughout the seminar, but would not force their realization. According to the principle of self-monitoring, essential decisions for the seminar's design and contents had been left to the responsibility of the students.

As part of the concept the participants were told to produce a blog, where they had to introduce a program which supported collaborative working. Every participant had to describe three of those services and/or programs over the period of the semester. For the display any number of posts was allowed to be published on the blog. Described programs have, for example, been Pivotal tracker $^{3}$, Zotero ${ }^{4}$, Mendeley ${ }^{5}$, GoogleDocs ${ }^{6}$, Dropbox ${ }^{7}$

$3 \mathrm{http}: / /$ www.pivotaltracker.com/

4 http://www.zotero.org/

$5 \mathrm{http}: / / \mathrm{www} . \mathrm{mendeley.com/}$

$6 \mathrm{http}: / /$ docs.google.com/?hl=de

7 http://www.dropbox.com/

8 Because of a too little number ofcase studies the learners have been

asked to give an extensive qualitative feedback for the class instead of a and many more. To enable a collaborative approach by the students, they were beholden to comment on each new post of their fellow students and to react on received comments. On this way it had been inevitable for everybody to also give attention to the ideas of others. Comments on the several programs often referred to privacy options or questions for compatibility of different programs. Every student engaged enthusiastically in the possibility to exchange opinions and to help.

The meetings in person with regard to the content, which to place every second week, have been completed with a beginning and ending session. During those meetings in person it had been decided on the meta level of the blog in common. This means that during the first meetings next to the instrumentality of content the blog itself had been constructed. It obtained a name and a template. Essential functions were decided on and then realized. All those decisions were made by the students themselves.

At the final meeting- in addition to the reflection of the own work and the evaluation ${ }^{8}$ of the course -possible future developments of the blog and its further design were discussed. The overall result of the evaluation showed that most of the students approved of the free operation. One student, for example, wrote "I want to accentuate that the seminar was really super". Even without having given strict and detailed elaborated instructions before, they managed to design a wellarranged, interesting and by all means helpful blog about collaborative working almost without any problems. The teacher's suggestions were accepted to some extent, partially they had also been modified or realized only in parts. After an initial phase of settling up the new working method a stringent collegiate participation was recorded. This was not only observed through their interest and participation, but especially because of them bringing in their own ideas, suggestions and experiences as well as criticism. Even if it was not possible to solve all - in particular technical - problems, the evaluation still showed that this didn't result in less participation but rather in supporting each other.

Additionally to this participation in academic education students did also participate in the mass media Internet. They published posts in their blogs and doing so contributed to structure a sector of the internet in parts. Furthermore, they've put together a well-organized summary of all services relevant in this sector. Indeed it cannot be spoken of as a complete overview, but this has neither been the aim of such a course nor been possible. Still the seminar's participants were able to acquaint themselves with unknown possibilities of participation in the internet and are capable - at least theoretically takeoff taking advantage of this in the future.

quantitative evaluation. This feedback is orientated on diverse central questions. The results, which have been made anonymous, are available for the authors. 


\section{Discussion about the adoption of collaboration in the case study}

The following implementations summarize the value of the seminar from a participant's perspective. Unlessstated otherwise they are based on the written feedback from the qualitative evaluation of the course.

The realization of the seminar 'Collaborative Working Online' enabled an acquirement of skills possible for the participants both on a theoretical level and on a practical. The learners acquired professional expertise on a theoretical level in terms of knowledge about collaborative working and about the work program and services online itself, which they had to describe. Because of the participation in the design process of the course contents in terms of a free choice of program, which they had to work with, the teacher noticed a certain students' insecurity. This was linked to the questions, whether the programs to be dealt with are really suitable for collaborative working. Because of this reason the involved students had to check and question the presented tool in every possible sector on its usability - an advance, which allowed and also required a profound approach of the practice of collaboration.

Beyond this the participants' methodical competences have been strengthened, too. Thus, information can be found in the evaluation, which shows that the importance of different sources has been gotten to know. From a teacher's perspective the students acquired great skills by questioning apparent certainties. In practice this skill has been necessary when analyzing presented services and programs critically. The services' producers haven't been the most significant source anymore.

On the practical level the evaluation texts do show a multitude of acquired competences. First of all, the involved students gathered technical competences. Next to composing appealing and concise texts they also learned the handling of the widespread blogging-software Wordpress. Moreover, they acquired advanced knowledge about the creation and editing of screencasts and screenshots. Eventually technical problems made it necessary for the students to adopt knowledge about video formats and their conversion. In this context students learned that the eligibility of a certain format depends on the platform, where it is supposed to be published later on. Because of taking part in this web civilization the inhibition threshold to participate in this new environment was reduced.

Additional to the technical skills, students were able to expand their social and self competence. They learned to improve their team working skills in this context. Their capacity for criticism and their empathy was trained. Furthermore they gained self confidence to approach new challenges, because of having been assigned responsibility and the need for permanent self-reflection. The participation in academic education had an activating effect on the students, with the result that the class was always been vital and informative for everybody involved - for the teacher as well as the students.

\section{Potentials and constraints for the adoption of media based collaboration in an academia context}

The significance of collaborative working will probably increase in the next couple of years. On the one hand it enables team work without being physically present, which is essential in a globalized world. On the other hand dealing with content in common produces an additional benefit in contrast to the very addition. Eventually constitutes collaboration a possibility of participation. Therefore, it can be a way to combine an increasingly competence orientated academic education with a humanistic claim for a free and responsible learner. Nevertheless this method is not to be adopted for its own sake. Both in an academic and a job-related context collaboration is simply a way to approach certain content can be approached. The content is supposed to appoint the eligibility of a method and not the other way round. Virtual collaboration is similarly critical. Problems, such as are equally in the e-learning sector, are to be considered. Thus, face-to-face meetings can be timesaving and reasonable in certain situations. With most of the tools presented in the blog containing only one aspect of collaborative working one would be soon exposed to a flood of programs in case of an exclusive participation in the web, whose maintenance would bring along a huge administrative effort. The danger of this is that the actual content of collaboration gets lost. Another very critical aspect of collaboration - in particular if this happens online - is freeloaders. Therefore, it's difficult and actually not even reasonable - to filter the work of every single person. In case one group member does not or barely participates in the overall job there should exist a tool to work against this development. This is the case for some of the programs presented in the blog as for example "teamspace4students". There exist control functions that record which team member undertook which step and at which time. On the one hand this is to be discussed because of saving the personal right of everybody; on the other hand this could help in a moderated way to stop the guild of freeloaders.

All in all the case study showed that collaboration depicts a reasonable method - for appropriate topics - to encourage students to participate on the one hand in academic education and on the other hand in the web.

Virtual collaborative working does not or only inferiorly play a role at universities. Tools like wikis and blogs are familiar to students from study courses with an affinity for media - but beyond those study courses barely any student knows and uses such tools for collaboration. In general there aren't any or rather hardly any seminars that try to explain to the students how to use the different 
programs. Still people stick to the slogan: Learning by Doing.

The case study described in this contribution shows that it's worth trying out and establishing this 'new' teachinglearning-process. Other studies in pedagogic psychological as well as in information scientific and media-didactic areas are necessary to gain well-founded results, which are able to show under which conditions the establishment of more students' participation in academic education can be achieved and by when, for example, virtual collaborative working is able to show some positive effects. To get to such analysis, however, the establishment of these teaching-learning-settings has to be tried out first.

\section{CONCLUSION}

The internet is an inherent part of young people's everyday life (compareBusemann \& Gscheidle, 2009; Busemann \& Gscheidle, 2010; Fisch \& Gscheidle, 2008) and is of paramount importance in public and political communication. Academia should therefore prepare for these new possibilities of interaction and participation. Instead, however, an appropriate competence development does not take place consistently enough. True to the motto private, public and academic spheres are to be separated learners do still lack ideas for the connecting factor most of the time.

The presented case study shows that corresponding learning concepts and designs are realizable. All the more there develops a convergence, which allows utilizing individual participation experiences from private and public areas for the context of academic education. This benefit, which can be seen by students gaining competence, has already been described.

A positive side effect of the above described seminar has been the free accessible blog 'Tools4You'. Everybody, who wants to work with increased possibilities of participation and collaboration, can find here suggestions about the different social media tools and how they can support them and the attending teacher in their realization of the requested contents. To secure the timelessness of the blog in the future it will be looked after as part of the 'Begleitstudium', an offer from the IMB, where students can get involved with projects (compare Sporer, \& Bredl 2011).

\section{References}

[1] Bente, G., Krämer, N.,\&Petersen, A. (2002) Virtuelle Realität als Gegenstand und Methode in der Psychologie. In Bente, G., Krämer, N.,\& Petersen, A. (Eds.), Virtuelle Realitäten (pp. 1-26). Göttingen: Hogrefe, Verlag für Psychologie.

[2] Blättel-Mink, B.,\& Hellmann, K.-U. (Eds.) (2010) Prosumer Revisited. Zur Aktualität einer Debatte. Wiesbaden: VS Verlag für Sozialwissenschaften.

[3] Bredl, K. (2008). Knowledge Sharing with Social Software - Wikis in Human Services. In Tochtermann, K. ,\& Maurer,
H. (Eds.), Proceedings of I-KNOW, 8th International Conference on Knowledge Management, Journal of Universal Computer Science, (pp.304-312). Graz, Austria, September 3-5.

[4] Bredl, K. \& Herz, D. (2010). Immersion in virtuellen Wissenswelten. In Hug, Th.,\& Maier, R. (Eds.), Medien Wissen - Bildung: Explorationen visualisierter und kollaborativer Wissensräume. Innsbruck: innsbruck university press (IUP).

[5] Bredl, K., Groß, A., Hünniger, J. \& Fleischer, J. (2012). The Avatar as a KnowledgeWorker? How Immersive 3D Virtual Environments may foster Knowledge Communication, Electronic Journal of Knowledge Management, Volume 10 Issue 1 (pp15-25).

[6] Bruns, A. (2010) Vom Prosumenten zum Produtzer. In Blättel-Mink, B.,\& Hellmann, K.-U. (Eds.),Prosumer Revisited. Zur Aktualität einer Debatte (pp.191-205). Wiesbaden: VS Verlag. für Sozialwissenschaften.

[7] Busemann, K., \&Gscheidle, Ch. (2009) Web 2.0: Communitys bei jungen Nutzern beliebt. Ergebnisse der ARD/ZDF-Onlinestudie 2009. Media Perspektiven, 7, 356364.

[8] Busemann, K., \& Gscheidle, Ch. (2010) Web 2.0: Nutzung steigt - Interesse an aktiver Teilhabe sinkt. Ergebnisse der ARD/ZDF-Onlinestudie 2010. Media Perspektiven, 7-8, 359-368.

[9] The EuropeanMinisters for Education (1999) Der Europäische Hochschulraum. Gemeinsame Erklärung der Europäischen Bildungsminister (,Bologna Erklärung“). Bologna, 19.06.1999. Retrieved from http://www.bmbf.de/pub/bologna_deu.pdf.

[10] Dietscher, Ch. (2005) Wie kann Partizipation zur schulischen Gesundheitsförderung beitragen? Wirkweisen und Umsetzungsoptionen. Paper session presented on „Partizipation und Diversity Management in der Gesundheitsfördernden Schule“. Retrieved from http://www.gesunde-schulen.ch/data/data_200.pdf.

[11] Dür, W. Bauer, M. M., Grossman, W., \&Mravlag, K. (2002) Partizipative Strukturen in der Schule und die Gesundheit von Jugendlichen im Alter von 11, 13 und 15 Jahren. Wien, LBIMGS. Retrieved from http://lbimgsarchiv.lbg.ac.at/berichte/hbsc18.pdf.

[12] Eckardt, Ph. (2005) Der Bologna-Prozess. Entstehung, Strukturen und Ziele der europäischen Hochschulreformpolitik. Norderstedt: Books on Demand.

[13] Fisch, M., \&Gscheidle, Ch. (2008) Mitmachnetz Web 2.0: Rege Beteiligung nur in Communitys. Ergebnisse der ARD/ZDF-Onlinestudie 2008. Media Perspektiven, 7, 356-364.

[14] Fleischer, J., Bredl, K., Hünniger, J. \& Weise, R. (2011).Online Collaboration - Computer Supported Collaborative Learning as a Student Involvement Opportunity. Paper presented at the 5th Annual Edition of International Technology, Education and Development Conference (INTED2011), Valencia (Spain), 7-9 March 2011.

[15] Gersmann, G., \& Mruck, K. (2006) Kollaboratives Schreiben. Trennung zwischen wissenschaftlichem Publizieren und informellem Kommunizieren wird zunehmend unterlaufen. Wissenschaftsmanagement, 1, 23.

[16] Honeycutt, C., \& Herring, S.C. (2009). Beyond Microblogging: Conversation and Collaboration via Twitter. Proceedings of the Forty-Second Hawai'i International Conference on System Sciences (HICSS-42). Los Alamitos, CA: IEEE Press.

[17] Hünniger, J., Fleischer, J. \& Bredl, K. (2011). Virtual 
Collaboration and Intercultural Learning at Universities. Poster presented at the 14th Biennial Conference European Association for Research on Learning and Instruction (EARLI 2011), Exeter, (UK), 30 August - 3 September 2011.

[18] Ketzer, Ch., Bredl, K. \& Fleischer, J. (2011). Zwischen mobilem Zwitschern und belangloser Kommunikation. Selbstdarstellung, Netzwerken und Informations-verhalten auf Twitter. In A. Frotschnig \& H. Raffaseder (Eds.) Forum Medientechnik - Next Generation, New Ideas.Boizenburg: Hülsbusch.

[19] Klaisubun, P., Honma, M., Kajondecha, P., \& Ishikawa, T. (2009) Awareness Information for Collaborative Information Gathering in Social Bookmarking Service. In Purvis, M., \& Savarimuthu, B.T.R. (Eds.) ICCMSN 2008 , LNAI 5322, (pp. 106-118). Berlin Heidelberg: SpringerVerlag.

[20] Koch, M., \& Richter, A (2007) Enterprise 2.0. Planung, Einführung und erfolgreicher Einsatz von Social Software in Unternehmen. München: Oldenbourg.

[21] Miller, V. (2008) New Media, Networking and Phatic Culture. Convergence: The International Journal of Research into New Media Technologies, 14(4), 387-400.

[22] Neumayer, M. (2008) Kollaboratives Lernen: Peacewiki eine Fallstudie. In Schachtner, Ch. (Ed.),Learning Communities. Das Internet als neuer Lern- und Wissensraum. (pp. 121-143). Frankfurt/Main: CampusVerlag.

[23] Reinmann, G. (inpress) Wie praktisch ist die Universität? Vom situierten zum forschenden Lernen mit digitalen Medien. In Schulz, M., \& Neusius A(Eds.),Tagungsband zum 6. Fernausbildungskongress der Bundeswehr.

[24] Saldern, M.v. (2008) Unterrichtsklima, Partizipation und soziale Interaktion. In Schweer, M. K. W. (Ed.),LehrerSchüler-Interaktion. Inhaltsfelder, Forschungsperspektiven und methodische Zugänge, (pp. 565-581). Wiesbaden: VS Verlag für Sozialwissenschaften.

[25] Jolie, S., Katzky, U., Bredl, K., Kappe, F. \& Krause, D. (2011). Lernen mit Simulationen und simulierten Welten. In Schaffert, S.,\& Ebner, M. (Eds.) Lehrbuch für Lernen und Lehren mit Technologien (L3T). Berlin: epubli. Retrievedfrom http://13t.eu/homepage/das-buch/ebook.

[26] Schweer, M. K. W. (Hg.) (2008): Lehrer-SchülerInteraktion. Inhaltsfelder, Forschungsperspektiven und methodische Zugänge. Wiesbaden: VS Verlag für Sozialwissenschaften.

[27] Sporer, T. \& Bredl, K. (2011) Fostering Reflective Practice through E-Portfolios in Higher Education.In Proceedings of World Conference on E-Learning in Corporate, Government, Healthcare, and Higher Education 2011 (pp. 1720-1724). VA: AACE. [28]

[29] Sturzenhecker, B. (2005) Begründungen und Qualitätsstandards von Partizipation - auch für Ganztagsschule. Jugendhilfe aktuell, 2, 30-34.

[30] Toffler, A. (1987) Die Dritte Welle - Zukunftschance. Perspektiven für die Gesellschaft des 21. Jahrhunderts. München: Goldmann.

[31] Wagner, Ch. (2009) Wiki and Beyond: Harnessing collective Inteligence through Web 2.0 technologies. AMCIS 2009 Proceedings. Paper 602.Retrieved from http://aisel.aisnet.org/amcis2009/602 